\title{
ASSESSMENT OF PLANT GERMINATION INTENSITY WITH THE USE OF AUTOMATED SYSTEM WITH COMPUTER VISION METHOD
}

\author{
Agnieszka Szparaga $^{\mathrm{a}^{*}}$, Ewa Czerwińska ${ }^{\mathrm{b}}$, Dariusz Tomkiewicz ${ }^{\mathrm{c}}$, Lesław Wilk $^{\mathrm{c}}$ \\ ${ }^{a}$ Department of Agrobiotechnology, Koszalin University of Technology \\ ${ }^{\mathrm{b}}$ Department of Biomedical Engineering, Koszalin University of Technology \\ ${ }^{\mathrm{c}}$ Department of Automatization, Mechanics and Construction, Koszalin University of Technology \\ *Corresponding author: e-mail: agnieszka.szparaga@tu.koszalin.pl
}

\begin{tabular}{|c|c|}
\hline ARTICLE INFO & ABSTRACT \\
\hline $\begin{array}{l}\text { Article history: } \\
\text { Received: March } 2017 \\
\text { Received in the revised form: } \\
\text { June } 2017 \\
\text { Accepted: July } 2017\end{array}$ & \multirow{2}{*}{$\begin{array}{l}\text { The objective of the paper was to show various options of using by } \\
\text { author an automated stand with computer image analysis for control of } \\
\text { plant germination on the example of cauliflower Brassica oleracea L. } \\
\text { 'Pionier" variety. The developed system consisted of a mobile plat- } \\
\text { form equipped with the acquisition and image processing system } \\
\text { based on Raspberry PL processor. Germination of cauliflower seeds } \\
\text { was the object of observation, which in one case were sown to soil } \\
\text { after dressing them with plant extracts (sweet flag Acorus calamus L., } \\
\text { great burdock roots Arctium lappa L.). In the other case, undressed } \\
\text { seeds were sown in the place of previous application of the above- } \\
\text { mentioned extracts. The use of a robot for monitoring plant germina- } \\
\text { tion enabled the automated analysis of the investigated material with } \\
\text { higher frequency than it has been possible so far. Simultaneously, } \\
\text { higher germination was reported when seeds were treated with macer- } \\
\text { ates and extracts from great burdock roots. }\end{array}$} \\
\hline $\begin{array}{l}\text { Key words: } \\
\text { computer image analysis } \\
\text { plant extracts } \\
\text { seeds } \\
\text { germination } \\
\text { cauliflower }\end{array}$ & \\
\hline
\end{tabular}

\section{Introduction}

The value of the sowing material considerably depends on substances which are used in plant protection for seed dressing. The increasing area of organic crops leads to limitation of the excessive use of chemical compounds for biological methods of crop protection and seeds quality (Grzesik et al., 2012).

There are numerous pathogens in soil therefore, pre-sowing seed pickling has become a necessity, since non-pickled seeds weakly germinate and infected seedlings underdevelop or die. As a result, it leads to the decline of the number of plants during the vegetation period and a low crop of the reduced quality. Thereby, alternative, non-chemical methods of pre-sow seed dressing based on natural antibacterial substances present in plants are searched for (Rochalska, Orzeszko-Rywka, Tracz, 2010; Orzeszko-Rywka, Rochalska, 2007; Rochalska, Orzeszko-Rywka, 2007). 
According to Oświecimski (2001) automatic control of crops may lead to better regulation of the plant growth and a higher yield (Oświęcimski, 2001). Furthermore, Doruchowski (2008) proves that the development of the modern agriculture takes place mainly based on biological, technical and social sciences. However, presently a clear turn to last technological developments has been observed (Doruchowski, 2008). Such a situation forces to search for IT technologies applications, such as computer image analysis. It is used in many scientific fields including agriculture. The use of IT techniques enables objective observation of biological processes. However, one should emphasise that the computer program is mainly a tool which helps later to formulate conclusions and hypotheses (Królczyk and Tukiendorf, 2006; Chojnacki and Tomkiewicz, 2008). The computer image analysis enables precise location of the objects defined by the program user. However, despite many advantages, there are also some obstacles such as limitations of the image representation or details recognition abilities. Therefore, development of this IT technology in agriculture is a significant element which ensures a balanced use of knowledge both with regard to biological and technical sciences (Tadeusiewicz and Kordocha, 1997; Tukiendorf et al., 2003; Królczyk and Tukiendorf, 2006; Dell’Aquila, 2004).

The objective of the paper was assessment of plant germinations on the example of cauliflower Brassica oleracea L. of Pioneer variety with the use of the computer image analysis.

\section{Research material and methods}

Undressed cauliflower seeds Brassica oleracea L. Pioneer variety constituted the research material. Germination ability of the sowing material used in the research was $80.92 \%$. For dressing seeds and in-soil application plant extracts in the form of water extracts as macerates, decoctions and infusions were used pursuant to methodology provided by SasPiotrowską, Piotrowskigo and Karczmarek-Cichosz (2004) and Tyszyńską-Kownacką andStarek (1989). Plants, which were used to produce extracts, were picked based on the pre vious in vitro experiment, which aimed at evaluation of germination ability and healthiness of cauliflower, whose seeds were treated with extracts in the form of infusions, macerates and decoction of various morphological parts of 40 plant species (Czerwińska et al., 2016). Research was carried out pursuant to the provisions of the International Seed Testing Association - Chapter 7 (ISTA 2013).

Extracts from sweet flag Acorus calamus L. and roots of great burdock Arctium lappa L. which in in vitro tests stimulated healthiness and liveliness of the analysed sowing material were used for treating seeds and for in-soil application (Table 1).

Assessment of germination after application of dressing was made on light soil from organic crops. The experiment was carried out in plastic containers for seedlings which consisted of 40 pots with a diameter and depth of $50 \mathrm{~mm}$. To each pot filled with soil, single seeds were sown to the depth of $15 \mathrm{~mm}$. Containers with sown seeds were placed in a chamber filled with water $(400 \mathrm{ml})$ which uniformly soaked to each pot. Soil moisture was $80 \%$ and the temperature of the surroundings for the duration of the test was $18^{\circ} \mathrm{C}$. For comparison of the efficiency of extracts two combinations were used:

- sowing material was treated by soaking seeds for 24 hours in water extracts and then seeds were dried by air on the filter paper and sowed to the soil;

- undressed seeds were soaked for 24 hours in distilled water, dried and sown to soil in the place of point application of $1 \mathrm{ml}$ of the suitable extract. 
Assessment of plant germination intensity...

The experiment was set in four iterations for each combination.

Table 1.

Water extracts with the best impact on cauliflower seed germination (\% in comparison to the control)

\begin{tabular}{lccc}
\hline Plant species & Extract form & Z1\% & Z5\% \\
\hline \multirow{2}{*}{ Acorus calamus L } & Macerate & 1.88 & -5.88 \\
& Infusion & 7.84 & -17.65 \\
& Decoction & 2.10 & -37.04 \\
\hline \multirow{2}{*}{ Arctium lappa $\mathrm{L}$} & Macerate & -7.84 & -111.76 \\
& Infusion & -11.28 & -17.65 \\
& Decoction & -1.80 & -25.93 \\
\hline
\end{tabular}

Z1 - germination ability, Z5 - seeds colonization with bacteria

The control object consisted of seeds undressed with plant extract, kept for 24 hours in distilled water and sown to soil without application of plant extracts.

The obtained results were developed statistically with the analysis of variance method (ANOVA) with a single classification $(\mathrm{P}=95 \%)$, separately for each plant from which extract was made, manner of preparation of these extracts and the method of extract application. The lowest significant difference was determined (Fisher test - NIR 0.05). The statistical analysis was performed with the use of ANW program (Analysis of Experiments Variance).

\section{A stand for control of the plant germination process and research results}

To obtain an image, a developed and made stand for control of the plant germination process was used. The stand consisted of a cart with the control system moving on the specially adjusted track. A system with acquisition and analysis of image which enables control of plant germination was placed on the cart. The acquisition and processing system was performed by Raspberry Pi computer Version 3. This computer is equipped with the Broadcom BCM 2387 processor, 64-bite quad-core ARM-8 $1.2 \mathrm{GHz}$ with integrated graphical system and 1 GB RAM memory. Raspberry Pi computer was responsible for registration, processing and sending images and estimation of the number of plant sprouts from the image. The system was equipped with a compatible camera with Raspberry Pi computer version NoIR which uses sensor Sony IMX219. The camera had a matrix which was sensitive to infrared light with a resolution of 8 Mega pixels. 3280x2464 pixel images were obtained. A special application for obtaining and analysis of the image was developed and written. It was written in Python language with the use of OpenCV library.

Several stages related to obtaining, processing and estimation of germinating plants number may be distinguished in the operation of the developed application for controlling the germination processes. These stages were presented in figure 1. 
Estimation of the measured size

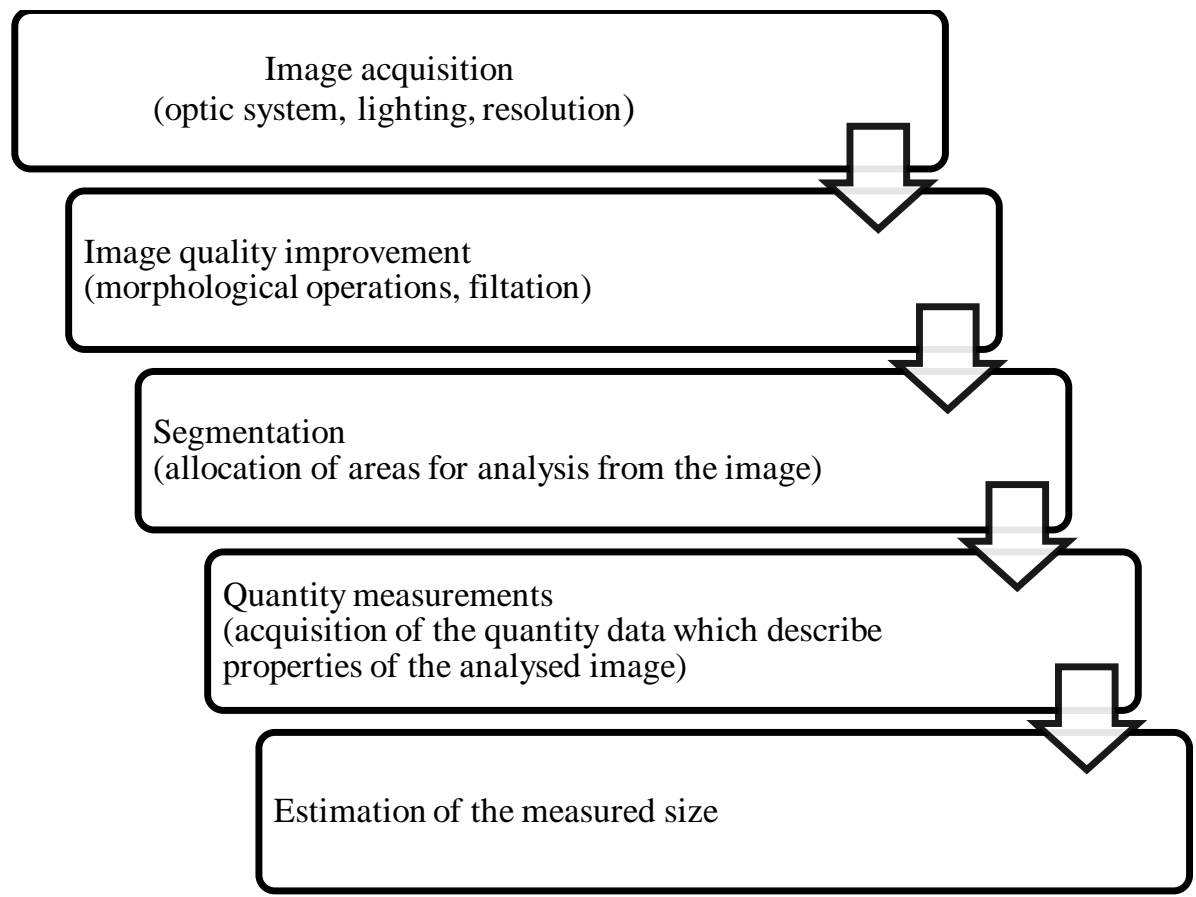

Figure 1. Stages of the image processing during operation of counting the number of germinating plants

The first stage of the measurements carried out with the method of image processing was image acquisition. During the stage of image acquisition the main problem was to acquire suitable lighting ensuring optimal conditions for further processing and data analysis. The developed system assumed operation in the conditions existing in a laboratory. In a laboratory and in the test stand, the light source during the day was sun whose rays were reaching the room through windows. This type of lighting causes problems related to its directional nature, the apparent movement of the sun during the day and the image acquisition system movement additionally impeded acquisition of the good quality image. Additional lighting was used at the stand, the aim of which was minimization of the sun light impact which was not fully possible and ensuring light at night.

Another stage of the image processing was improvement of the image quality. Images acquired from the first stage had a non-uniform background caused by reflection of the light from the non-uniform soil structure and the containers edge. Direction of the light caused that very light areas were formed which impeded further analysis of the image (Fig.2). 


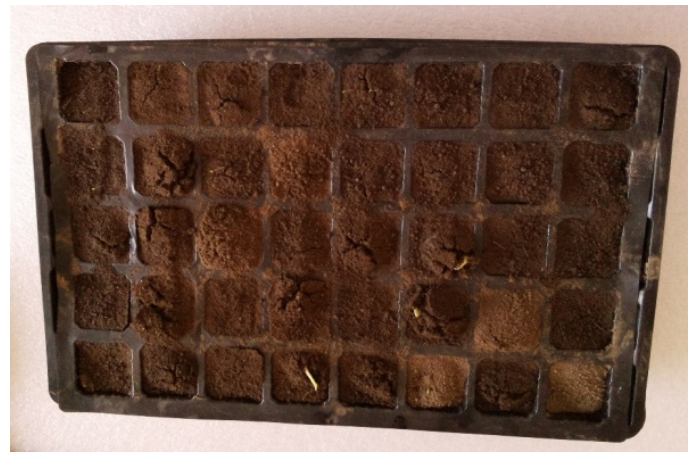

Figure 2. Single image acquired by the system
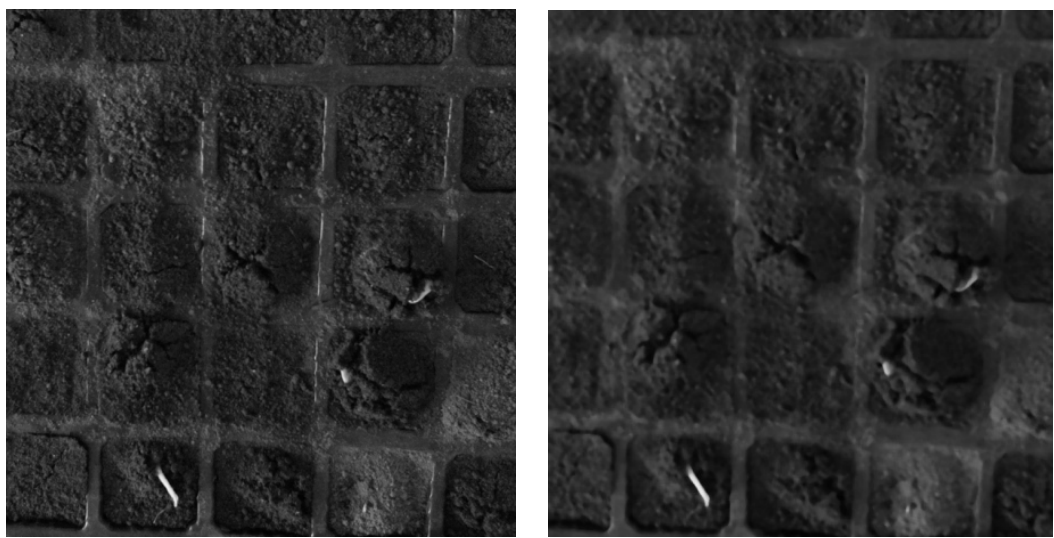

Figure 3. Piece of image with removed red and

Figure 4. Piece of image after low-pass filtration blue element

In order to reduce those disruptions for further use only data responsible for intensity of green colour in image (Fig. 3) were used and a median low-pass filter (Fig.4) and morphological operations were used. The second stage consisted in the image segmentation. For this purpose histogramic segmentation and labelling were applied. For the selected area of the image, methods enabling quantitative description of the image properties were used. Values of properties were used for classification whether the identified areas are plant sprouts. It was assumed that the number of found sprouts is identical as the number of the selected areas which meet the qualitative conditions (Fig.5). This assumption was verified by comparison of the areas selected by the application with areas indicated on unprocessed images by an expert.

In case of sprouts whose area was bigger than approx. $5 \mathrm{~mm}^{2}$, estimation was compliant with values determined by the expert. 


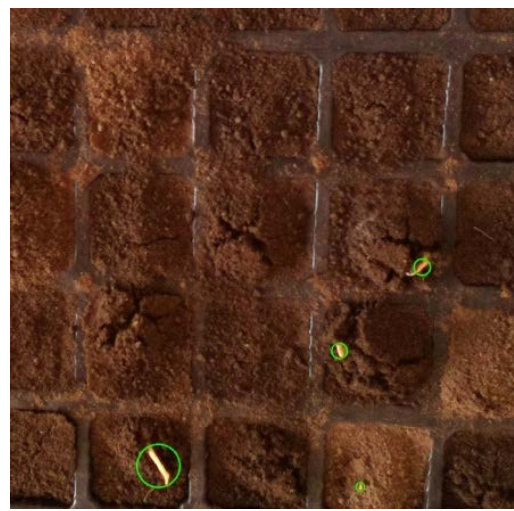

Figure 5. Piece of image with marked areas (green circle) where program revealed plant sprouts

Cauliflower germination in soil after the use of water extracts from great burdock started on the third day after sowing, both in case of in-soil application as well as treated seeds.

On the first days of germination periods $(4,5,6$ day from sowing) the average percent of seedlings obtained from seeds dressed with plant extracts and from soil after application of extracts was at the similar level.

A higher number of germinating plants was reported in case of in-soil application of extracts but the highest number of germinations took place after application of extract to soil in the form of macerate (44\% of germinations after 15 days from sowing).

In the remaining investigated combinations i.e. control and dressed seeds, the final ability of germination was lower. Germination of plants after treating seeds with extracts were higher in case of the use of infusions (39\% of germination after 15 days from sowing), however in comparison to the remaining ones they were at a similar level (macerate $37 \%$, decoction 38\%). In comparison to the control in both combinations of the experiment significantly higher germination of plants after the use of plant extracts were reported.

Cauliflower germinations after the use of water extracts from sweet flag (Table 2) were reported as early as two days from sowing after seeds were dressed with water extracts in the form of infusion and decoction, while for control samples and in-soil application - after 3 days from sowing. From among the used extracts in case of in-soil application, infusions stimulated plant germination the most successfully (after 15 days from sowing, the number of germinated plants was 43\%) in comparison to macerates (41\% of germination), decoction (38\% of germination). It was stated that the average number of plant germination in soil after application of water extracts was higher in comparison to the results reported for control (25\% of germination after 15 days). 
Assessment of plant germination intensity...

Table 2.

Dynamics of cauliflower germination (\%)

\begin{tabular}{|c|c|c|c|c|c|c|c|c|c|c|c|c|c|}
\hline \multirow[t]{3}{*}{ Days } & \multicolumn{6}{|c|}{ Application on seeds } & \multirow[t]{3}{*}{ Control } & \multicolumn{6}{|c|}{ In-soil application } \\
\hline & \multicolumn{2}{|c|}{ Macerate } & \multicolumn{2}{|c|}{ Infusion } & \multicolumn{2}{|c|}{ Decoction } & & \multicolumn{2}{|c|}{ Macerate } & \multicolumn{2}{|c|}{ Infusion } & \multicolumn{2}{|c|}{ Decoction } \\
\hline & 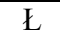 & $\mathrm{T}$ & 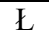 & $\mathrm{T}$ & 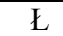 & $\mathrm{T}$ & & Ł & $\mathrm{T}$ & $\ell$ & $\mathrm{T}$ & 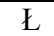 & $\mathrm{T}$ \\
\hline 1 & 0 & 0 & 0 & 0 & 0 & 0 & 0 & 0 & 0 & 0 & 0 & 0 & 0 \\
\hline 2 & 0 & 0 & 0 & 2 & 5 & 3 & 0 & 0 & 0 & 0 & 0 & 0 & 0 \\
\hline 3 & 7 & 3 & 4 & 6 & 13 & 4 & 11 & 8 & 5 & 6 & 6 & 6 & 4 \\
\hline 4 & 12 & 8 & 10 & 10 & 21 & 14 & 17 & 14 & 10 & 8 & 14 & 15 & 13 \\
\hline 5 & 17 & 18 & 23 & 19 & 29 & 19 & 21 & 19 & 18 & 23 & 26 & 24 & 18 \\
\hline 6 & 22 & 20 & 25 & 26 & 30 & 25 & 21 & 22 & 23 & 24 & 27 & 29 & 23 \\
\hline 7 & 31 & 27 & 28 & 29 & 36 & 29 & 22 & 30 & 26 & 29 & 30 & 30 & 30 \\
\hline 8 & 33 & 30 & 29 & 33 & 36 & 29 & 22 & 35 & 36 & 36 & 36 & 36 & 36 \\
\hline 9 & 34 & 31 & 35 & 35 & 36 & 30 & 24 & 38 & 37 & 39 & 37 & 39 & 37 \\
\hline 10 & 35 & 32 & 36 & 36 & 36 & 31 & 24 & 39 & 37 & 39 & 37 & 39 & 37 \\
\hline 11 & 35 & 33 & 38 & 36 & 37 & 31 & 24 & 41 & 38 & 40 & 39 & 39 & 37 \\
\hline 12 & 35 & 34 & 39 & 38 & 38 & 32 & 25 & 41 & 39 & 40 & 40 & 39 & 38 \\
\hline 13 & 37 & 34 & 39 & 39 & 38 & 33 & 25 & 41 & 40 & 41 & 42 & 39 & 38 \\
\hline 14 & 37 & 36 & 39 & 40 & 38 & 35 & 25 & 42 & 41 & 42 & 43 & 39 & 38 \\
\hline 15 & 37 & 36 & 39 & 40 & 38 & 35 & 25 & 44 & 41 & 42 & 43 & 39 & 38 \\
\hline $\begin{array}{l}\text { NIR } \\
1,1\end{array}$ & & $\mathrm{~N}$ & & & $\begin{array}{l}\text { NIR } \\
1,8\end{array}$ & & & & $\begin{array}{c}\text { NIR } \\
2,2\end{array}$ & & & & \\
\hline
\end{tabular}

Legend: $\mathrm{\ell}$ - extract from great burdock roots, $\mathrm{T}$ - extract from sweet flag

In case of dressing seeds, from the used extracts, infusions were the best for germinations (40\% of germination after 15 days from sowing). Also in this case, it was stated that the use of seed dressing from sweet flag stimulated the plant germination because their number was significantly higher in comparison to germination of plants treated as a control namely without dressing (25\% of germination after 15 days from sowing). The observed germination in both combinations enabled determination that application of water extracts to soil was more stimulating for seed germination in comparison to dressed seeds.

\section{Conclusions}

1. The use of the computer image analysis enabled automatic assessment of the investigated material. However, estimation of the number of occurring plants was impeded. It caused a necessity of solving the problems related to elimination of variable lighting conditions and the movement of the image acquisition system.

2. Application of plant extracts caused the increase of cauliflower germination ability in comparison to control seeds. Significantly, the highest number of germinated plants was reported in case of in-soil application of tested plant preparations.

3. Macerates and infusions obtained from great burdock roots influenced the ability of cauliflower germination in comparison to extracts made of great burdock roots. 


\section{References}

Chojnacki, J., Tomkiewicz, D. (2008). Zastosowanie programu Labview do wyznaczania przeżywalności owadobójczych nicieni - biologicznego środka ochrony roślin, Inżynieria Rolnicza, 11(109), 33-38.

Czerwińska E., Piskier, T., Szparaga, A. (2016). Wplyw zaprawiania wyciagami roślinnymi na zdolność kietkowania i kontaminacje nasion kalafiora Brassica oleracea L. w Wybrane zagadnienia ekologiczne we współczesnym rolnictwie pod red. Zbytek Z. Wydawnictwo Przemysłowy Instytut Maszyn Rolniczych, Poznań.

Dell'Aquila, A. (2004). Application of a computer-aided image analysis to evaluate seed germination under different environment al conditions, Italian Journal of Agronomy, 8(1), 51-62.

Doruchowski G. (2008). Postęp i nowe koncepcje w rolnictwie precyzyjnym, Inżynieria Rolnicza, 12(107), 19-31.

Grzesik, M., Janas, R. Górnik, K. Romanowska-Duda, Z. (2012). Biological and physical methods of seed production and processing, Biologiczne $\mathrm{i}$ fizyczne metody stosowane $\mathrm{w}$ produkcji $\mathrm{i}$ uszlachetnianiu nasion, Journal of Research and Applications in Agricultural Engineering, 57(3), 147-152.

Królczyk, J., Tukiendorf, M. (2006). Wykorzystanie metody komputerowej analizy obrazu w ocenie stanu liści na przykładzie klonu pospolitego (Acer platanoide), Inżynieria Rolnicza, 5, 349-354.

Tukiendorf, M., Boss, J., Krótkiewicz, M. (2003). An application of picture analysis as a method of evaluation of granular blend's quality, Polish Journal of Food and Nutrition Sciences, 12/53, 2, 27-30.

Orzeszko-Rywka, A., Rochalska, M._(2007). Preliminary assessment of efficiency of some ecological methods of sugar beet seed dressing, Journal of Research and Applications in Agricultural Engineering, 52(4), 10-13.

Oświęcimski, W., 2001, Monitorowanie upraw i klimatu w uprawie pomidorów szklarniowych. Jak doprowadzić do lepszego wyrównania wzrostu roślin i wyższych plonów? Hasło Ogrodnicze, 12, 44-45.

Rochalska, M., Orzeszko-Rywka, A. (2009). Zastosowanie naturalnych substancji roślinnych jako zapraw nasiennych dla upraw ekologicznych, Journal of Research and Applications in Agricultural Engineering, 54(4), 74-80.

Rochalska, M., Orzeszko-Rywka, A., Tracz, M. (2010). Estimation efficiency of powdered herbs of crop seeds treatment, Journal of Research and Applications in Agricultural Engineering, 55(4), 67-72.

Sas-Piotrowska, B, Piotrowski, W., Karczmarek-Cichosz, R. (2004). Plant extracts and their influence on some properties of seeds of cultivated plants - grain plants, Annual Set the Environment Protection, 6, 77-89.

Tadeusiewicz, R., Kordocha, P. (1997). Komputerowa analiza i przetwarzanie obrazów. Kraków, Wydawnictwo Fundacji Postępy Telekomunikacji. ISBN 83-86476-15-X.

Tyszyńska-Kownacka, D., Starek, T. (1989). Zioła w polskim domu. Wydawnictwo Warta, Warszawa. ISBN:83-225-0230-3. 
Assessment of plant germination intensity...

\title{
OCENA INTENSYWNOŚCI WSCHODÓW ROŚLIN Z ZASTOSOWANIEM ZAUTOMATYZOWANEGO UKLADU WYKORZYSTUJĄCEGO METODY WIZJI KOMPUTEROWEJ
}

\begin{abstract}
Streszczenie. Celem pracy było wykazanie możliwości zastosowania opracowanego przez autorów zautomatyzowanego stanowiska wykorzystującego metody komputerowej analizy obrazu do monitorowana procesu wschodów roślin na przykładzie kalafiora Brassica oleracea L. odmiany 'Pionier'. Opracowany układ składał się z mobilnej platformy wyposażonej system akwizycji i przetwarzania obrazu oparty na procesorze Raspberry PI. Obiektem obserwowanym były wschody nasion kalafiora, które w jednym przypadku wysiano do gleby po zaprawieniu ich wyciągami z roślin (korzeni tataraku zwyczajnego Acorus calamus L., korzeni łopianu większego Arctium lappa L.), natomiast w drugim wysiewano nasiona niezaprawiane w miejscu wcześniejszej aplikacji w/w ekstraktów. Zastosowanie robota do monitorowania wschodów roślin pozwoliło na zautomatyzowaną analizę badanego materiału z dużo większą częstotliwością niż było to możliwe do tej pory. Jednocześnie stwierdzono wyższe wschody, gdy nasiona traktowano maceratami i naparami z korzeni łopianu większego.
\end{abstract}

Słowa kluczowe: komputerowa analiza obrazu, wyciągi roślinne, nasiona, wschody, kalafior 